\title{
THE IMPACT OF SOCIAL SUPPORT ON THE QUALITY OF LIFE OF THE ELDERLY FROM RURAL AREAS
}

\author{
Despotovic Milena ${ }^{1}$, Ristic Ignjatovic Draganal, Sbutega Milosevic Gorica ${ }^{2}$, Despotovic Mile ${ }^{3}$, Antic Ljiljana ${ }^{3}$ \\ ${ }^{1}$ Faculty of Medical Sciences University of Kragujevac, Serbia \\ 2 University of Belgrade Faculty of Medicine, Belgrade, Serbia \\ ${ }^{3}$ The Academy of Applied Preschool Teaching and Health Studies, Krusevac, Serbia
}

\section{UTICAJ SOCIJALNE PODRŠKE NA KVALITET ŽIVOTA STARIH IZ RURALNIH PODRUČJA}

\author{
Despotović Milenal, Ristić Ignjatović Draganal, Sbutega Milošević Gorica ${ }^{2}$, Despotović Mile ${ }^{3}$, Antić Ljiljana ${ }^{3}$ \\ ${ }^{1}$ Fakultet medicinskih nauka Univerziteta u Kragujevcu, Kragujevac \\ ${ }_{2}^{2}$ Medicinski fakultet Univerziteta u Beogradu, Beograd \\ ${ }_{3}^{3}$ Akademija vaspitačko-medicinskih strukovnih studija u Kruševcu, odsek Cuprija, Kruševac
}

\section{ABSTRACT}

Objective. The purpose of this article is to explore social support influence on the quality of life of elderly people from rural areas and to examine whether there are differences between the quality of life of the old people living in the family and those who live alone.

Methods. An epidemiological observation study was performed, and it was a cross section study. The sample consisted of 110 subjects. Berlin Social Support scale was used with the aim to measure social support, and to assess the quality of life a 10-point Likert scale was used. Normal $K-K$ Plot and histogram graphs were used to test the agreement of the sample distributions with the normal distribution, as well as the tests: Kolmogorov-Smirnov and Shapiro-Wilk. The Kruskal Wallis and Wilkisson test sum scores were used to test for differences in overall social support and the quality of life.

Results. All social support parameters affect life satisfaction. These differences are statistically significant $(p<0.05)$, which was also shown by Spirman's correlation. Respondents who rated the relationships with housemates as excellent had the highest average grade of satisfaction with life (7.38), while those who rated these relationships as horrible had the lowest average grade of satisfaction with life (1.57). Frequent contacts with close relatives and friends on a weekly basis correlate with a greater life satisfaction degree.

Conclusion. It can be concluded that the index of total social support and all of its subgroups correlate with subjective life satisfaction of elders.

Key words: social support; quality of life; aged

\section{INTRODUCTION}

Social support represents the issue is of particular importance for the preservation of mental and physical health. It represents the willingness of people from the environment to provide assistance and support to those who are in difficult life situations. The basic tasks of social support should include the discovery of positive personality potentials and finding resources for their realization, improvement of interpersonal skills and communication between different subjects; finding the

\section{SAŽETAK}

Cilj. Cilj ovog rada bio je da ispita da li socijalna podrška utiče na kvalitet života starih koji žive u ruralnom području i da li postoje razlike između kvaliteta života starih koji žive u porodici i onih koji žive izvan nje.

Metode. Sprovedena je epidemiološka opservaciona studija po tipu studije preseka. Uzorak je bio sastavljen od 110 ispitanika. Za merenje socijalne podrške korišćena je Berlinska skala socijalne podrške, a za procenu kvaliteta života desetostepena skala Likertovog tipa. Za ispitivanje saglasnosti uzoračkih raspodela s normalnom raspodelom korišćeni su grafici: Normal Q-Q Plot i Histogram, kao $i$ testovi Kolmogorov-Smirnov i Shapiro-Vilk. Za testiranje razlika u oceni kvaliteta života i ukupnoj socijalnoj podršci korišćeni su Kruskal Vallis $i$ Vilcoxon rank sum test.

Rezultati. Svi parametri socijalne podrške utiču na zadovoljstvo životom. Ispitanici koji su odnose sa ukućanima ocenjivali kao odlične imali su najveću prosečnu ocenu zadovoljstva životom (7,38), dok su oni koji su odnose ocenjivali kao užasne imali najnižu prosečnu ocenu zadovoljstva životom (1,57). Česti kontakti s bliskim rođacima i prijateljima na nedeljnom nivou, kao i kontakti sa osobama van kruga primarne i sekundarne mreže na nedeljnom nivou koreliraju sa višim stepenom zadovoljstva životom.

Zaključak. Može se zaključiti da indeks ukupne socijalne podrške i svih njenih potkategorija korelira sa subjektivnim zadovoljstvom životom kod starih.

Ključne reči: socijalna podrška; kvalitet života; stari

best ways to overcome life crises with constant empowerment of an individual. Characteristics of social support networks depend on the characteristics and needs of the individual receiving support. The presence and development of social support networks, or their absence, can affect the functioning of the individual in the community (1).

Social support networks often define the way in which an individual sees themselves. Adequate social support enables both recipients and support providers to 
understand their potential and their needs. Through interaction with others, providing or receiving support, an individual learns to recognize his inner potentials and based on them develops and improves the sense of self. So far, in scientific literature, the concept of social support has been widely researched. Social support is a factor that has influence on the effects of challenging life experiences and potential crises, and it can help overcoming them. Social support can affect self-esteem and self-image creation (1). It is well known that people who have poor social support more often suffer from anxiety or depression compared to those with higher social support. Also, people who have low social support have much greater rates of all mental disorders, including posttraumatic stress syndrome, social phobia, panic disorder, clinical depression (2-5). The research shows that $41 \%$ of people suffering from depression had a loss of at least one parent in their early childhood, which can be connected with poor social support, and that people who have adequate social support in childhood function better in adulthood (1). It has also been found that social support has an impact on the adaptation of individuals in chronic high stress, such as HIV infections (6), in patients with rheumatoid arthritis (7), cancer (8), stroke (9) and coronary diseases (10). Social support greatly affects physical well-being, as well as mortality. Those with low social support are facing risk of death due to various illnesses (11), while people with higher social support have higher chances of survival (12). Persons with lower levels of social support have more chances to suffer from cardiovascular diseases (13), various inflammatory processes (14), have a weaker immune system (15), and more complications during pregnancy (16). On the other hand, greater levels of social support reduce delivery time and improve mother-child interaction. It also reduces the amount of drugs taken to manage asthma diseases, contributes to more successful recovery from surgery, and prolongs life expectancy (1). In addition to numerous benefits, the presence of social support providers can be the reason of physiological and neuroendocrine activity.

The researchers today pay attention on the way social support influence the quality of life of different social groups. Quality of life (QOL) can be described as overall well-being of groups or individuals. Quality of life indicators include not only economic factors, but also leisure time, environment, mental and physical health and social functioning (17). The quality of life in relation to health (HRQOL) refers to the assessment of how the presence of various diseases affects the general well-being of a human (18).

Considering the existing trend of prolonged life expectancy, modern societies are becoming more and more societies with high percentages of elderly people, we should pay more attention to research on the social support influence on the quality of life of older people. The aging of the Serbian population will be the reason of a significant reduction in general workforce in future. This could have negative influence on the national economy. Therefore, we need to create programs that will promote continuous learning and social policy reforms for elderly population (19). It is necessary that the new programs provide social security for the elderly, both those from urban and rural areas of our country. The role of the family in meeting the needs of the elderly in Serbia is significant and multiple - the majority of the elderly relies on family support in meeting different needs and "it can be assumed that it includes more than $90 \%$ of the elderly" (20). The reform of the pension system is also necessary, since the current pension system is still not comprehensive and does not guarantee the full social security of the elderly. In addition, it of particular importance to consider health care of the elderly, as health legislation has a great influence on the positions of the older population.

Bearing in mind all the above, the authors of this work made a survey aimed at examining whether social support has influence on older population quality of life and to examine whether there are differences between the quality of life of older people living with family and those who live alone.

\section{SUBJECTS AND METHODS}

This research was designed as an epidemiological observational study, according to the type of cross-section study. The research was performed in the population of the old inhabitants in the rural area of the city of Jagodina, in November and December 2014, in the Health Center in Jagodina, the village clinics and private houses. Based on the documentation of the health institution Health Center in Jagodina, 110 respondents were randomly selected. The study included only respondents who could fill in the questionnaire alone.

For the needs of the research, the data collection questionnaire was created. The questionnaire contained several parts relating to: personal and demographic characteristics, family characteristics, social networks and social support. To measure social support, standardized instrument was used - the Berlin Social Support Scale (21). This instrument has 6 psychometric scales (the perception of available instrumental and emotional support, seeking support, needed support, provided support, just received support and the effect of protective buffering), and a total of 48 items. To test and measure the value of quality of life, Lickert type subjective well-being scale was used, so respondents could rate life satisfaction from 0 to 10 (22).

In order to test the accordance of sample distribution with normal distribution, the following graphs were used: 
Normal Q-Q Plot and Histogram, as well as tests: Kolmogorov-Smirnov and Shapiro-Wilk. Descriptive statistics were used to describe the parameters of importance, depending on their nature: percentages, frequencies, median, standard deviation, range and mean. Kruskal Wallis and Wilcoxon ranked sum test were used to test differences in assessment of social support and life quality. The analysis of data was made in the statistical program R (downloaded: 10/22/2014) Microsoft Office Word 2010 and Microsoft Office Excel 2010 were used to graphically display data.

\section{RESULTS}

The survey included 110 respondents of both sexes, inhabited in the rural areas of Jagodina. The number of women was slightly higher than the number of men. The average age of the respondents was 75.59 years. Most respondents had not completed primary school, while the number of those with completed college or university was the smallest. Most of the respondents were retired workers who had spent their lifetime in a company. The largest number of respondents had retired over 10 years before $62.73 \%$ i.e. 69 of them; while $13(11.82 \%)$ respondents had retired 5 to 10 years ago, while the same number of people had retired in the last 5 years. Fifteen people did not have a pension (13.64\%).

Respondents who were married made $51.82 \%$ of the sample. Widows and widowers made $40 \%$ of the sample, and they were followed by divorced ones with $5.45 \%$ of the sample, while only $2.73 \%$ of respondents had never married. Respondents without children made $7.27 \%$ of the sample. Those who had had children before, and at the moment of study did not have, made $5.45 \%$ of the sample. A total of $22.73 \%$ of respondents had one child. The largest number of respondents $(51.82 \%)$ had two children, while $12.73 \%$ of the respondents had three or more children. Respondents who lived alone made $20.91 \%$ of the sample. The respondents who lived only with their spouse made $29.09 \%$ of the sample, the respondents who lived with children and their spouse made $7.27 \%$, while respondents who lived with grandchildren, children and their spouse made $14.55 \%$. The respondents living with children only made $3.64 \%$ of the sample, while those who lived with children and grandchildren account for $22.73 \%$ of the sample. Only $1.82 \%$ of the respondents lived with their relatives.

The average number of household members was 3.25. The largest number of respondents rated their relationships with the housemates as excellent (38.18\% of respondents), followed by respondents who rated family relationships as good (25.45\%). Few respondents estimate relationships with housemates as bad $(9.09 \%)$ or terrible $(6.36 \%)$. The question was not applicable to respondents living alone $(20.91 \%)$. The average number of close friends and relatives contacted on a weekly basis was 9.53, while the average number of acquaintances they communicated with, or saw them, was 12.45. Respondents who saw or called 5 to 10 close friends or relatives weekly made $48.18 \%$ of the sample. Those who communicated with 5 to 10 acquaintance per week made $34.55 \%$ of the sample, while those who contacted with more than 10 acquaintances per week made $33.64 \%$ of the total sample. The following table showed the average values of social support categories based on the Berlin scale (Table 1). Respondents rated life satisfaction with an average grade of 5.78 .

The results showed that respondents who had a spouse rated life satisfaction with higher grades (6.37) compared to those who did not have a partner (5.15). The described differences are statistically significant $(p<0.05)$. The household structure, as well as the number of children did not have an influence on the quality of life evaluation. In these categories, significant statistical differences were not observed ( $p>0.05)$. Relationships with housemates significantly influenced the quality of life of the respondents. The respondents who rated the relationships with housemates as excellent had the highest average grade of satisfaction with life (7.38), followed by those who rated them as good (5.71). The respondents who rated relations with family members as poor had an average grade of 3.4, while those who rated relationships as

Table 1. Average values of social support categories based on the Berlin scale.

\begin{tabular}{|l|c|c|c|}
\hline Characteristics & $\mathrm{N}(\%)$ & Mean (SD) & Median \\
\hline Perception of available support & $110(100 \%)$ & $25.34(5.91)$ & $26(10-37)$ \\
\hline Perception of available emotional support & $110(100 \%)$ & $12.53(3.16)$ & $13(4-17)$ \\
\hline Perception of available instrumental support & $110(100 \%)$ & $12.88(3.38)$ & $14(4-19)$ \\
\hline Need for support & $110(100 \%)$ & $4.66(3.62)$ & $5(-1-13)$ \\
\hline Seeking for support & $110(100 \%)$ & $13.07(4.41)$ & $13(5-20)$ \\
\hline Just received support & $110(100 \%)$ & $34.53(11.61)$ & $38.5(0-45)$ \\
\hline Provided support & $110(100 \%)$ & $34.71(5.65)$ & $35.5(12-49)$ \\
\hline Scale of protective buffering & $110(100 \%)$ & $15.47(5.21)$ & $16.5(5-28)$ \\
\hline Total social support & $110(100 \%)$ & $127.2(25.89)$ & $132(57-173)$ \\
\hline
\end{tabular}


Table 2. Impact of social support parameters on life satisfaction

\begin{tabular}{|c|c|c|c|c|}
\hline \multirow[t]{2}{*}{ Characteristics } & \multicolumn{3}{|c|}{ Descriptive data } & \multirow[t]{2}{*}{ Spearmanran correlation } \\
\hline & $\mathrm{N}(\%)$ & Mean (SD) & Median & \\
\hline \multicolumn{5}{|c|}{ Perception of available support } \\
\hline Perception of available support & $110(100 \%)$ & $25.34(5.91)$ & $\begin{array}{c}26 \\
(10-37)\end{array}$ & \multirow[t]{2}{*}{$\begin{array}{c}\rho=0.5203286 \\
p=0\end{array}$} \\
\hline Life satisfaction & $110(100 \%)$ & $\begin{array}{c}5.78 \\
(2.64)\end{array}$ & $\begin{array}{c}5 \\
(0-10)\end{array}$ & \\
\hline \multicolumn{5}{|c|}{ Perception of available emotional support } \\
\hline Perception of available support & $110(100 \%)$ & $12.53(3.16)$ & $\begin{array}{c}13 \\
(4-17)\end{array}$ & \multirow[t]{2}{*}{$\begin{array}{c}\rho=0.514504 \\
p=0\end{array}$} \\
\hline Life satisfaction & $110(100 \%)$ & $\begin{array}{c}5.78 \\
(2.64)\end{array}$ & $\begin{array}{c}5 \\
(0-10)\end{array}$ & \\
\hline \multicolumn{5}{|c|}{ Perception of available instrumental support } \\
\hline Perception of available emotional support & $110(100 \%)$ & $\begin{array}{l}12.88 \\
(3.38)\end{array}$ & $\begin{array}{c}14 \\
(4-19)\end{array}$ & \multirow[t]{2}{*}{$\begin{array}{c}\rho=0.3953367 \\
p=2 \cdot 10^{-5}\end{array}$} \\
\hline Life satisfaction & $110(100 \%)$ & $\begin{array}{c}5.78 \\
(2.64)\end{array}$ & $\begin{array}{c}5 \\
(0-10)\end{array}$ & \\
\hline \multicolumn{5}{|c|}{ Need for support } \\
\hline Need for support & $110(100 \%)$ & $\begin{array}{c}4.66 \\
(3.62)\end{array}$ & $\begin{array}{c}5 \\
(-1-13)\end{array}$ & \multirow[t]{2}{*}{$\begin{array}{c}\rho=0.4411598 \\
p=0\end{array}$} \\
\hline Life satisfaction & $110(100 \%)$ & $\begin{array}{c}5.78 \\
(2.64) \\
\end{array}$ & $\begin{array}{c}5 \\
(0-10) \\
\end{array}$ & \\
\hline \multicolumn{5}{|c|}{ Searching for support } \\
\hline Searching for support & $110(100 \%)$ & $13.07(4.41)$ & $\begin{array}{c}13 \\
(5-20)\end{array}$ & \multirow[t]{2}{*}{$\begin{array}{c}\rho=0.4585136 \\
p=0\end{array}$} \\
\hline Life satisfaction & $110(100 \%)$ & $\begin{array}{c}5.78 \\
(2.64) \\
\end{array}$ & $\begin{array}{c}5 \\
(0-10) \\
\end{array}$ & \\
\hline \multicolumn{5}{|c|}{ Just received support } \\
\hline Just received support & $110(100 \%)$ & $34.53(11.61)$ & $\begin{array}{c}38.5 \\
(0-45)\end{array}$ & \multirow[t]{2}{*}{$\begin{array}{c}\rho=0.5857939 \\
p=0\end{array}$} \\
\hline Life satisfaction & $110(100 \%)$ & $\begin{array}{c}5.78 \\
(2.64)\end{array}$ & $\begin{array}{c}5 \\
(0-10)\end{array}$ & \\
\hline \multicolumn{5}{|c|}{ Provided support } \\
\hline Provided support & $110(100 \%)$ & $34.71(5.65)$ & $\begin{array}{c}38.5 \\
(12-49)\end{array}$ & \multirow[t]{2}{*}{$\begin{array}{c}\rho=0.5036567 \\
p=0\end{array}$} \\
\hline Life satisfaction & $110(100 \%)$ & $\begin{array}{c}5.78 \\
(2.64)\end{array}$ & $\begin{array}{c}5 \\
(0-10)\end{array}$ & \\
\hline \multicolumn{5}{|c|}{ Scale of protective buffering } \\
\hline Scale of protective buffering & $110(100 \%)$ & $15.47(5.21)$ & $\begin{array}{c}16.5 \\
(5-28)\end{array}$ & \multirow[t]{2}{*}{$\begin{array}{c}\rho=0.1697799 \\
p=0.07619\end{array}$} \\
\hline Life satisfaction & $110(100 \%)$ & $\begin{array}{c}5.78 \\
(2.64)\end{array}$ & $\begin{array}{c}5 \\
(0-10)\end{array}$ & \\
\hline \multicolumn{5}{|c|}{ Total social support } \\
\hline Total social support & $110(100 \%)$ & $127.2(25.89)$ & $\begin{array}{c}132 \\
(57-173)\end{array}$ & \multirow[t]{2}{*}{$\begin{array}{c}\rho=0.6400866 \\
p=0\end{array}$} \\
\hline Life satisfaction & $110(100 \%)$ & $5.78(2.64)$ & $\begin{array}{c}5 \\
(0-10)\end{array}$ & \\
\hline
\end{tabular}


horrible had the lowest average grade of life satisfaction (1.57). Frequent contacts with close relatives and friends on weekly basis, as well as contacts with other people, from both primary and secondary network on weekly basis, correlated with a higher degree of life satisfaction.

The research has shown that all parameters of social support (Berlin scale) affect life satisfaction. These differences are statistically significant $(p<0.05)$, which was also shown by Spearman's correlation, as can be seen in Table 2.

\section{DISCUSSION}

The main hypothesis of this research is that social support existence affects the quality of life of the older population from rural areas of the city of Jagodina, and that family support and development of social networks result in a better quality of life. Numerous previous studies on social support confirmed the correlation of the quality of life and social support parameters. As the elderly population becomes an increasingly important part of modern societies, and as it is a vulnerable population group (mostly due to increased health risks and characteristics of the third age), there is a need to determine the exact position of this population and identify all the factors that can have influence on the older population quality of life, in order to create new strategies for improving the situation of the elderly and their empowerment.

Great attention is paid to social support and its aspects, because adequate social support brings the potential for better quality of life for old people. A Brazilian survey conducted in 2014 found that older people from urban areas showed greater interest in the quality of life compared to rural elderly, although the old ones from rural areas had a much higher rate in fields of physical, psychological and social relations (23). The existence of a social network and social support seems particularly important for the rural elderly quality of life, precisely because of the characteristics and aspects of the environment they are living in. Our research confirmed results of previous research carried out in this area. Considering that there is a statistically significant correlation between the quality of life and social support, it can be concluded that social support is an extremely important determinant of the quality of life of the elderly. Additionally, using Spirman's correlation test, our research confirmed moderate correlation between different aspects of social support and the quality of life tested (rho $=0.50$ -0.75). The impact of social support on the quality of life is undeniable, but it should be noted that often the specifics of social support are determined by demographic, socio-economic, as well as cultural and family characteristics. Thus, this research confirmed a statistically significant difference between factors that largely determine social support, such as family characteristics, as well as characteristics of the social network, and life satisfaction used for measuring the quality of life. Depending on the existence and characteristics of all of these factors, we can speak about the adequacy of social support and its positive or negative impact.

As the family is often regarded as the most significant social support sources, this part deserves special attention. In terms of structure, functions and value orientation, there are several types of families (24). Family development goes through several stages. It is believed that elderly people most often live in families that are in the last two stages: the family left by the children- abandoned nest, and the family with a retired spouse. However, due to the cultural reasons, the specificities of the rural environment, and economic reasons, in the rural areas of our country multi-generation families in which elderly parents live with children and grandchildren are still common, so there is no reason to talk about the degree of the abandoned nest. The specificity of the environment determines the dynamics and values of the family. One of the main functions of the family relates to socialization and social support, which speaks about the family as a link between the individual and the society. Interpersonal relations among members are crucial for the proper functioning of the family. Harmonious family relationships enable better functioning of the individual in society. Through family support, the individual is empowered and encouraged to successfully solve the problem and prevail the crisis. On the other hand, any weakness, maladministration or breakdown of connections between family members leads to family disorganization, resulting in reduced sources of help for an individual, when necessary, reduced family support, and thus even poorer quality of life of an individual in some cases.

The causes of family disorganization should be sought in: incompatibility of family members' responses to external circumstances, economic individualism, cultural differentiation among members, individualization of life patterns (24). The marital status of the respondents is one of the characteristics that can be seen as social support source with influence on the quality of life. The study found that respondents with a spouse assess life satisfaction with higher grades than those who do not have a partner. In this category, a significant statistical difference was observed $(p=0.02)$. The majority of respondents have two children.

The importance of marriage is highlighted by numerous studies. The results of the study conducted by Gutiérrez Vega and colleagues confirmed a connection between the quality of life and marital status and support coming from partner in older people living in the areas of 
border region of Mexico and the United States (25). Despotovic states that respondents who live in some kind of partner relationship have greater levels of the quality of life (5.96) than people without a partner (5.06) (26). He also finds that respondents who have children rate the quality of life with higher grades in relation to those who have never had children ( 6.16 for those who have children, 4.5 for those who never had them or lost them), contrary to this research where differences have not been observed. The household structure is defined based on the number of people, from one-member households to multi-member households. Totally $33.64 \%$ of respondents live in multimember households, which is almost a third of the population surveyed. This data can be compared with official statistical data indicating that in the territory of Central Serbia in 1991, there were $20.9 \%$ of households with five or more members (1). Considering that participants of our research were from the rural environments, a higher percentage of multi-member households and multi-generation families should not be a surprise.

In our study, the evaluation of the quality of life was not affected by household structure or children number. A Japanese study by Okabayashi proved that the number of children is an important source of social support when it comes to the older female population. Liu, Han and associates investigate the protective effect of the connection between the quality of life and the structure of the family. These authors used instrumentally variable approach. According to them, the quality of life of those without children or having only one daughter is considerably lower compared to the elderly who had at least one son (27). This result can be explained by the cultural differences and specificities of societies. The largest number of respondents rated their relationships with the housemates as excellent (38.18\% of respondents). The relationships with housemates significantly influence the quality of life of the respondents. The respondents who rated these relationships as excellent had the highest average grades of satisfaction with life (7.38), followed by those who rated them as good (5.71). The respondents who rated relations with family members as bad had an average satisfaction grade of 3.4, while those who rated relationships as horrible had the lowest average grade of life satisfaction (1.57). Santini, Kounagi, Turovolas and Haro are examining the link between the quality of interpersonal relationships and the social network with suicidal ideas and depression in married elderly. An important task of the study is to find the connection between mental health outcomes and social relationships. By analyzing the Irish Longitudinal Study of Aging Tilda, the authors found that negative partner interactions were connected with increased possibilities for suicidal ideation, anxiety and depression. On the contrary, this research confirmed that positive partner interactions were inversely proportional to suicidal ideation as well as anxiety (28). In his doctoral dissertation M. Despotovic points out that respondents who have excellent relationships with their house members rate the quality of life with higher grades (6.34), unlike those who regard them as horrible (2.63) (26). Family relations and household structure are important factors of social support, and their imbalance certainly leads to feeling of loneliness among the elderly. Testing indirect social support effects, one of the studies investigated if depression has any influence on loneliness (29). The scale of emotional and social loneliness was filled by 320 older people, while the multidimensional exchange of perceptions of social support was evaluated. The results confirmed connection between both social support and loneliness and depression. Statistical analysis has shown that loneliness and depression are partlly mediated by social support.

It should be emphasized that individuals and families are part of wider social networks and are in constant interaction with them. A social network is a complex structure that is influenced by many factors. In addition to family connections that are separately considered, and which are an indispensable part of the social network, particular attention should be paid to the social contacts of the surveyed population. A significant statistical quality of life difference is found among the respondents who were employed in a company, and those who were farmers or housewives. People employed in a company rated life satisfaction 6.5 , in contrast to farmers and housewives, whose average score was 5.04. This situation can be explained by the fact that people who worked in companies moved into a larger social circle and worked with a large number of different people, and with some of them they established friendly relationships and thus expanded their social network.

Another parameter indirectly speaks in favor of the usefulness of the social network and social capital. Namely, respondents who drank coffee in society were considerably more satisfied with life (average score 6.1) than those who drank it themselves (4.14), and these differences were statistically significant. It has been found that frequent contacts with close relatives and friends on a weekly basis, as well as contacts with people out of primary and secondary network on a weekly basis, correlating with a higher degree of life satisfaction. Also, respondents who have a phone are more satisfied with their lives. Those who use it and talk to friends or relatives on a daily basis, rate the quality of life with a mean score of 6.01, while those who do not have a phone rate life satisfaction with a mean score of 2.29. Medvene, Nilsen and associates explore the connection between social networks characteristics and loneliness and isolation in older population. They observed networks types and their 
structural characteristics. Also, they examined how a kind of social network is related to social isolation, quality of relationships and social isolation. Forty personal interviews were conducted with the elderly in order to explore social networks structures, which is described by the contact frequency with family and friends, as well as participation in various social and religious groups. Almost half of the social networks of participants is made by family members, while less than one third is made by friends. Findings indicate that isolation and loneliness of respondents are related to the types of social networks to which they are linked (30). Study by Taiana aimed to discover if the subjective well-being of the elderly is influenced by intergenerational social support. This author found out that intergenerational social support, self-esteem and loneliness, self-esteem and intergenerational social support are significantly connected to subjective wellbeing. This author has also found that loneliness as well as self-esteem are characteristics that are partially mediated by the connection between social support and the subjective well-being of the old people (31). Chen and associates believe that depression symptoms are often found in elderly and that majority of the older studies dealt with individual characteristics of the individual or economic factors. Their study wanted to measure if social and physical characteristics of the neighborhood had an impact on depression. A total of 400 elderly people from four poor housing estates in Hong Kong were interviewed in a cross-sectional survey. The following areas: demography, daily life activities, neighborhood support networks recent history of life and proximity to community institution were examined. The results showed that symptoms of depression were associated with everyday life activities as well as income. (32). Zapata and associates claimed that elders feel vulnerable because of loneliness. Also, some elders, mostly women, express a sense of neglect despite of general satisfaction with family (33). Lucumi, Gomez, Bronson and Para carried out a study in which they explored socio-economic status, social capital and health-related quality of life among the elderly in Bogota. (34) The results of this study spoke about weak neighborhood networks, as even $93 \%$ of the total sample stated that their neighbors would use them when they could, and only $20 \%$ of the respondents said they believed in common neighborly values. Another recent study highlights the importance of social networks. A group of Israeli authors identified the factors that contribute to happiness in the elderly in Israel (35). Among these factors is the development of the social network. Similar results came from Moeini and associates who found that high level of social support lead to feelings of happiness among the elderly in Iran (36).

The results of all the mentioned studies confirmed the data that we have come to as well, meaning that we can speak of the global trend and the common characteristics of the older population, regardless of the cultural factors. This data can be used for the development of elderlyoriented public health strategies.

We can conclude that the index of total social support and all of its subgroups correlate with subjective life satisfaction among the elderly from the rural areas of the city of Jagodina. Family support parameters influence subjective life satisfaction ratings. Better relations with the housemates and the presence of partners provide greater subjective assessment of life satisfaction. Family support is a significant factor in overall social support. More frequent social contacts with close friends and acquaintances correlate with subjective life satisfaction among the elderly from the rural areas of the city of Jagodina. Previous research carried out in the field of public health, as well as other fields of science, has established the link between assessment of the quality of life of respondents and social support parameters, which our research has confirmed.

The challenges of the modern era, such as constant stress and uncertain life, certainly affect not only the development of the social network, but also overall quality of life. Strong social network and especially good family relations provide the social support that becomes the source of human physical, cognitive, emotional, psychological, and social development, and this is especially important for the elderly population, given the longer life expectancy and the concept of active aging. If this support is adequate and if it can successfully meet the challenges and provide protection to the elderly person, when necessary, we can talk about family and social support that provides better quality and satisfaction with life. Due to the specific nature of the rural areas and the specific nature of the rural environment, as well as the challenges faced by the rural population, such as increasing loneliness and isolation, it can be concluded that this research was not only justified, but also necessary.

\section{REFERENCES}

1. Drča J. Society and elders. Novi Sad: Prometej. 2013. (in Serbian).

2. Brewin CR, Andrews B, Valentine JD. Meta-analysis of risk factors for posttraumatic stress disorder in trauma-exposed adults. J Consult Clin Psychol 2008, 68: 748-66.

3. Huang M, Yen C, Lung, F. Moderators and mediators among panic, agoraphobia symptoms, and suicidal ideation in patients with panic disorder. Compr Psychiatry 2010; 51: 243-9.

4. Torgrud L, Walker J, Murray L, Cox B, Chartier M, Kjernisted, K. Deficits in perceived social support associated with generalized social phobia. Cogn Behav Ther 2004; 33: 87-96. 
5. Lakey B, Cronin A. Low social support and major depression: research, theory, and methodological issues. In: Dobson KS, Dozois D, eds. Risk factors for depression. Amsterdam, Boston: Academic Press, 2008.

6. Brennan-Ing M, Seidel L, Karpiak SE. Social support systems and social network characteristics of older adults with HIV. Interdiscip Top Gerontol Geriatr 2017; 42: 159-72.

7. Rzeszutek M, Oniszczenko W, Kwiatkowska B. Stress coping strategies, spirituality, social support and posttraumatic growth in a Polish sample of rheumatoid arthritis patients. Psychol Health Med 2017; 22: 10828.

8. Fong AJ, Scarapicchia TMF, McDonough $\mathrm{MH}$, Wrosch C, Sabiston CM. Changes in social support predict emotional well-being in breast cancer survivors. Psychooncology 2017; 26: 664-71.

9. Northcott S, Moss B, Harrison K, Hilari K. A systematic review of the impact of stroke on social support and social networks: associated factors and patterns of change. Clin Rehabil 2016; 30: 811-31.

10. Karatas T, Bostanoglu H. Perceived social support and psychosocial adjustment in patients with coronary heart disease. Int J Nurs Pract 2017; 23. (doi: 10.1111/ijn.12558).

11. Uchino B. Social support and physical health: understanding the health consequences of relationships. New Haven: Yale University Press, 2004.

12. Valentiner DP, Holahan CJ, Moos RH. Social support, appraisals of event controllability, and coping: an integrative model. J Pers Soc Psychol 1994; 66: 1094102.

13. Chou A, Stewart A, Wild C, MS, Bloom J. Social support and survival in young women with breast carcinoma. Psychooncology 2012; 21: 125-33.

14. Hughes S, Jaremka LM, Alfano CM, et al. Social support predicts inflammation, pain, and depressive symptoms: longitudinal relationships among breast cancer survivors. Psychoneuroendocrinology 2014; 42: $38-44$.

15. Copertaro A, Bracci M, Manzella N, Barbaresi M, Copertaro B, Santarelli L. Low perceived social support is associated with CD8+CD57+ lymphocyte expansion and increased TNF- $\alpha$ levels. Biomed Res Int 2014; 2014: 635784. (doi: 10.1155/2014/635784).

16. Chu PS, Saucier DA, Hafner E. Meta-analysis of the relationships between social support and well-being in children and adolescents. J Soc Clin Psychol 2010; 29: 624-45.
17. Derek G. Johnston R. Pratt G. Watts M, et al. Quality of life. Dictionary of human geography. 5th ed. Oxford: Wiley-Blackwell, 2009.

18. Health Related Quality of Life Concepts. HealthRelated Quality of Life (HRQOL). HRQOL Concepts. Atlanta: Center for Disease Control and Prevention, 2018. (http://www.cdc.gov/hrqol/concept.htm).

19. Vukovic D. Social security. Belgrade: Čigoja, 2009. (in Serbian).

20. Sauer M. Comparing long-term protection regimes - a case study of Serbia. In: Vukovic D, Perisic N, eds. Risks and challenges of social reforms. Belgrade: Faculty of Political Science, 2012: 86.

21. Schulz U, Schwarzer R. Soziale Unterstützung bei der Krankheitsbewältigung. Die Berliner Social Support Skalen (BSSS) [Social support in coping with illness: The Berlin Social Support Scales (BSSS)]. Diagnostica 2003; 49: 73-82. (in German).

22. Despotovic M, Jankovic S, Ilic B. Measuring the impact of social networking and social support on the health and quality of life of the elderly. PONS Med J 2012; 9: 70-6. (in Serbian).

23. dos Santos Tavares DM, Fernandes Bolina A, Aparecida Dias F, dos Santos Ferreira PC, José Haas V. Quality of life of elderly. Comparison between urban and rural areas. Invest Educ Enferm 2014; 32: 401-13.

24. Milić A. Sociology of family. Belgrade: Čigoja, 2007. (in Serbian).

25. Gutiérrez-Vega M, Esparza-Del Villar OA, CarrilloSaucedo IC, Montañez-Alvarado P. The possible protective effect of marital status in quality of life among elders in a U.S.-Mexico border city. Community Ment Health J 2018; 54: 480-4.

26. Despotovic M. Social support as a factor in the health and quality of life of the elderly with hypertension. Doctoral dissertation. Kragujevac. University of Kragujevac, 2014. (in Serbian).

27. Liu H, Han X, Xiao Q, Li S, Feldman MW. Family structure and quality of life of elders in rural China: the role of the new rural social pension. J Aging Soc Policy 2015; 27: 123-38.

28. Ivan Santini Z, Koyanagi A, Tyrovolas S, Haro JM. The association of relationship quality and social networks with depression, anxiety, and suicidal ideation among older married adults: Findings from a cross-sectional analysis of the Irish Longitudinal Study on Ageing (TILDA). J Affect Disord 2015; 179: 134-41.

29. Liu L, Gou Z, Zuo J.Social support mediates loneliness and depression in elderly people. J Health Psychol 2016; 21: 750-8. 
30. Medvene LJ1, Nilsen KM, Smith R, et al. Social networks and links to isolation and loneliness among elderly HCBS clients. Aging Ment Health 2016; 20: 485-93.

31. Tian Q. Intergeneration social support affects the subjective well-being of the elderly: Mediator roles of self-esteem and loneliness. J Health Psychol 2016; 21: $1137-44$

32. Chen YY, Wong GH, Lum TY, Lou VW, Ho AH, Luo H, Tong TL. Neighborhood support network, perceived proximity to community facilities and depressive symptoms among low socioeconomic status Chinese elders. Aging Ment Health 2016; 20: 423-31.

33. Zapata-López BI, Delgado-Villamizar NL,CardonaArango D. Social and family support to the elderly in urban areas. Rev Salud Publica (Bogota) 2015; 17: 848-60.
34. Lucumí DI, Gomez LF, Brownson RC, Parra DC. Social capital, socioeconomic status, and healthrelated quality of life among older adults in Bogotá (Colombia). J Aging Health 2015; 27: 730-50.

35. Zamir A, Granek L, Carmel S. Factors affecting the will to live among elderly jews living in israel. Aging Ment Health 2018: 1-7. (doi: 10.1080/13607863.2018.1537361).

36. Moeini B, Barati M, Farhadian M, Ara MH. The association between social support and happiness among elderly in Iran. Korean J Fam Med 2018; 39: 260-5. 